
of psychological disorders among pediatric patients. Journal of Education, Health and Sport. 2019;9(12):82-86. eISSN 2391-8306. DOI http://dx.doi.org/10.12775/JEHS.2019.09.12.009

https://apcz.umk.pl/czasopisma/index.php/JEHS/article/view/JEHS.2019.09.12.009

https://zenodo.org/record/3586118

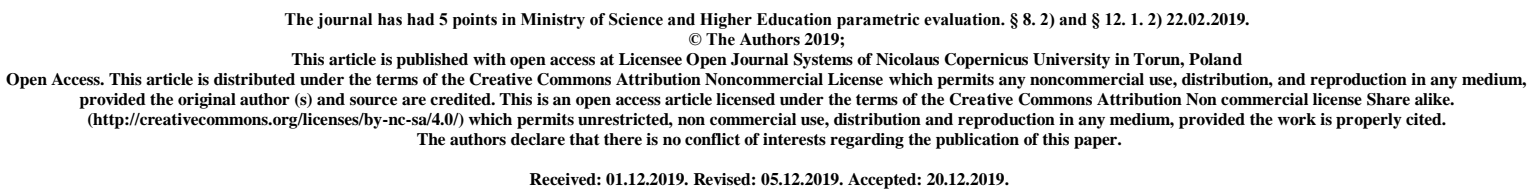

\title{
Temporomandibular joint dysfunctions in the context of psychological disorders among pediatric patients
}

\section{Dysfunkcje stawu skroniowo-żuchwowego w kontekście zaburzeń psychologicznych wśród pacjentów pediatrycznych}

A. Zuszek ${ }^{1}$, agnieszka.zuszek@gmail.com, ORCID: 0000-0002-3944-1941

J. Borek ${ }^{1,2,3}$, joanna.monika.borek@ gmail.com, ORCID: 0000-0003-3959-7214

R.Malak², rmalak@ump.edu.pl, ORCID: 0000-0003-0521-5249

W.Samborski², samborskiw@tlen.pl, ORCID: 0000-0002-0338-894

1 Studenckie Koło Naukowe „Open Physiotherapy”, Uniwersytet Medyczny im. Karola Marcinkowskiego w Poznaniu

2 Pracownia Rehabilitacji Fizjoterapii Reumatologicznej, Katedra i Klinika Reumatologii i Rehabilitacji, Uniwersytet Medyczny im. K. Marcinkowskiego w Poznaniu 3 Katedra i Klinika Ortopedii Szczękowej i Ortodoncji, Uniwersytet Medyczny im. K. Marcinkowskiego w Poznaniu

${ }^{1}$ Students Scientific Society "Open Physiotherapy", Poznan University of Medical Sciences

${ }^{2}$ Department of Rheumatology and Rehabilitation, Poznan University of Medical Sciences

${ }^{3}$ Department and Clinic of Maxillofacial Orthopaedics and Orthodontics, Poznan University of Medical Sciences

\begin{abstract}
There are many factors that affect temporomandibular joint dysfunction. These may include, among others: structural and postural disorders, bruxism, and occlusive abnormalities. In addition, an important aspect are psychological factors that, as a result of stress, can affect temporomandibular joint disorders through hyperactivity of the muscles, followed by biomechanical changes and related pain. These factors can lead to the production of neurotransmitters that disturb the balance of serotonin and catecholamines. Aim: Literature review to determine the relationship between temporomandibular joint disorders and psychological disorders in pediatric patients Material and methods: Based on the Research Gate, PubMed and Google Scholar databases, a review of scientific papers was performed
\end{abstract}


using the keywords: (temporomandibular joint), (stress, bruxism, mental disorders). Articles from the last 5 years have been analyzed. Results: Higher levels of anxiety are observed in patients with temporomandibular joint disorders. There is also a higher incidence of depression and chronic stress. Conclusions: Available literature shows the relationships between dysfunctions within the temporomandibular joint and mental disorders of the patient. However, research in this area should continue to show more detailed information regarding both the general relationship between the abovementioned aspects and the relationship between individual temporomandibular joint disorders and psychological aspects.

Key words: Temporomandibular disorders; stress; depression

\section{Introduction}

Temporomandibular joint disorders are one of the most common facial cranial dysfunctions. They usually affect young adults and middle-aged adults, and are less common in children and the elderly. They can have various grounds - from tooth defects, jaw, jaw and other elements of the skull, through posture defects, up to mental disorders. Temporomandibular joint dysfunction can cause, among others, headache, facial muscle pain, intracranial disorders, e.g. crackling, problems in chewing food [1,2,3]. Temporomandibular joint disorders often go hand in hand with psychological disorders of patients. Higher levels of anxiety are often seen in people with temporomandibular joint disorders. A higher frequency of depression and chronic stress is also noted [4,5]. The way the human body reacts to stress can sometimes be positive, for example when we make quick decisions and react immediately in the face of a potential threat [6]. People respond to stressful situations by increasing the expression of adrenocorticotropic hormone and cortisol [7]. Repeatedly stressful events can affect the excessive activation of the hypothalamus, pituitary gland, adrenal glands, thereby increasing the level of cortisol that is released during a stressful event [8]. When examining a patient, every risk factor for temporomandibular joint disorders should be considered in order to properly diagnose the patient and plan the therapeutic process.

\section{Aim}

This paper reviews the literature on the relationship between temporomandibular joint dysfunctions and mental disorders of the patient.

\section{Material and methods}

A review of the literature was conducted in terms of the relationship between mental disorders and psychological problems of the patient and the occurrence of temporomandibular joint dysfunction. This work is for reference only. A review of the PubMed research database resources was carried out using the keywords: (temporomandibular joint), (stress, bruxism, mental disorders). The following inclusion criteria were used in the study:

1. The participants of selected analyzes were people from the age of two to the age of 18 .

2. The researchers of individual articles were to demonstrate the relationship between the temporomandibular joint abnormalities and the patient's mental disorders.

The researchers considered the exclusion criteria to be:

1. Previous oncological and neurological diseases, patients with multiple sclerosis, epilepsy.

2. Articles in which patients of various ages were examined, making the research group heterogeneous.

The authors focused on reports published in English and Polish. Finally, the authors chose to discuss 6 articles, which were characterized in Table 1 and in the descriptive content. 


\section{Results}

According to the authors of this work, in the studies presented there are links between dysfunctions within the temporomandibular joint and mental disorders of the patient. Higher levels of anxiety are often seen in people with temporomandibular joint disorders. A higher incidence of depression and chronic stress is also noted. However, the authors emphasize the shortage of sufficient scientific evidence to support the above-mentioned correlation. The greater part of scientific research is carried out without taking into account the control group or with improperly planned research work, for example by selecting the wrong research group or measuring tests.

The problem under consideration in this work was presented in a tabular study - Table 1, which includes the studies: Pereira et al. [9], Pizolato et al. [10], Al-Khotani et al. [11], Kobayashi et al. [12], Sampaio et al. [13], Sermet Elbay et al. [14].

Tab. 1 Characteristics of individual research works.

\begin{tabular}{|c|c|c|c|c|c|}
\hline Author & $\begin{array}{l}\text { Research } \\
\text { group }\end{array}$ & Age & Type of tests used & Research goal & Summary \\
\hline $\begin{array}{l}\text { Pereira et } \\
\text { al., } 2009\end{array}$ & 558 people & 12 years & $\begin{array}{lr}\text { GCPS } & \text { (Graded } \\
\text { Chronic } & \text { Pain } \\
\text { Scale) } & \text { and } \\
\text { depression } & \text { and } \\
\text { somatization } & \text { were } \\
\text { measured } & \end{array}$ & $\begin{array}{l}\text { Assessment of the } \\
\text { relationship between } \\
\text { psychological variables and } \\
\text { clinical diagnosis of } \\
\text { temporomandibular joint } \\
\text { disorders. }\end{array}$ & $\begin{array}{l}\text { The psychological aspect and } \\
\text { female gender are significant risk } \\
\text { indicators associated with TMD, } \\
\text { even in children. }\end{array}$ \\
\hline $\begin{array}{l}\text { Pizolato et } \\
\text { al., } 2013\end{array}$ & $\begin{array}{l}\text { Research } \\
\text { group - } 40 \\
\text { Control group } \\
-42\end{array}$ & $9-12$ years & $\begin{array}{l}\text { HADS- Hospital } \\
\text { Anxiety and } \\
\text { Depression Scale }\end{array}$ & 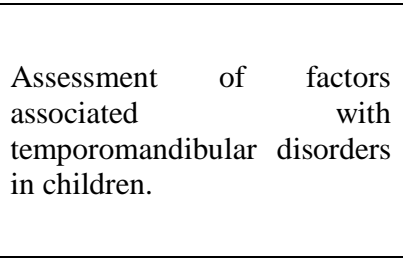 & $\begin{array}{l}\text { According to the authors, open } \\
\text { mouth and anxiety levels were } \\
\text { associated with temporomandibular } \\
\text { joint disorders in children. Due to } \\
\text { the cross-section of this study, } \\
\text { observed relationships may have } \\
\text { a two-way relationship. }\end{array}$ \\
\hline $\begin{array}{l}\text { Al- } \\
\text { Khotani et } \\
\text { al., } 2017\end{array}$ & 456 people & $10-18$ years & $\begin{array}{l}\text { Research } \\
\text { Diagnostic } \\
\text { Criteria for TMD } \\
\text { for axes I and II, } \\
\text { and then assessed } \\
\text { their problem } \\
\text { according to the } \\
\text { Youth Self Report } \\
\text { scale }\end{array}$ & $\begin{array}{l}\text { Examined whether } \\
\text { psychosocial problems, } \\
\text { amongst which the stress, } \\
\text { anxiety and depression, are } \\
\text { associated with disorders of } \\
\text { the temporomandibular joint, } \\
\text { both occurrences of pain and } \\
\text { no pain in this joint. }\end{array}$ & $\begin{array}{l}\text { Pain in the temporomandibular } \\
\text { joints in children and adolescents } \\
\text { does not affect social activity. } \\
\text { Temporomandibular joint pain may } \\
\text { be strongly associated with } \\
\text { emotional functioning, with higher } \\
\text { frequencies of anxiety, depression } \\
\text { than children and adolescents } \\
\text { without TMD pain. }\end{array}$ \\
\hline $\begin{array}{l}\text { Kobayashi } \\
\text { et al., } \\
2017\end{array}$ & $\begin{array}{l}\text { Research } \\
\text { group - } 38 \\
\text { Control group } \\
-38\end{array}$ & $7-14$ years & $\begin{array}{l}\text { MASC-(Brazilian } \\
\text { Version) - } \\
\text { Multidimensional } \\
\text { Anxiety Scale for } \\
\text { Children }\end{array}$ & $\begin{array}{l}\text { It was examined whether } \\
\text { the level of salivary amylase } \\
\text { and cortisol and the } \\
\text { occurrence of anxiety } \\
\text { symptoms differed in children } \\
\text { presenting disorders in the } \\
\text { temporomandibular joints. }\end{array}$ & $\begin{array}{l}\text { Children with temporomandibular } \\
\text { joint disorders had higher scores } \\
\text { in the assessment of anxiety } \\
\text { symptoms. However, no difference } \\
\text { was observed in the secretion } \\
\text { profile of salivary stress parameters } \\
\text { between paired groups of children } \\
\text { with and without TMD. }\end{array}$ \\
\hline $\begin{array}{l}\text { Sampaio } \\
\text { et al., } \\
2018\end{array}$ & $\begin{array}{l}\text { Research } \\
\text { group - } 48 \\
\text { Control group } \\
-36\end{array}$ & $6-10$ years & $\begin{array}{l}\text { LSSI - Lipp Stress } \\
\text { Symptom } \\
\text { Inventory } \\
\text { CSS -Child Stress } \\
\text { Scale }\end{array}$ & $\begin{array}{l}\text { The incidence of bruxism } \\
\text { during sleep in children and } \\
\text { their mothers relative to stress } \\
\text { was investigated. }\end{array}$ & $\begin{array}{l}\text { Mental stress did not show } \\
\text { a statistically } \\
\text { relationship with sleep bruxism in } \\
\text { either mothers or their child. }\end{array}$ \\
\hline $\begin{array}{l}\text { Sermet } \\
\text { Elbay et } \\
\text { al., } 2016\end{array}$ & $\begin{array}{l}\text { Research } \\
\text { group - } 184 \\
\text { Control group } \\
-201\end{array}$ & $8-18$ years & $\begin{array}{l}\text { Questionnaire } \\
\text { taking into } \\
\text { account the } \\
\text { coverage of TMD }\end{array}$ & $\begin{array}{l}\text { The frequencies of the } \\
\text { temporomandibular joint } \\
\text { disorders in children living } \\
\text { with their parents and } \\
\text { children living in care and } \\
\text { education facilities were } \\
\text { assessed and compared. }\end{array}$ & $\begin{array}{l}\text { A relationship has been } \\
\text { demonstrated between } \\
\text { temporomandibular joint disorders } \\
\text { and stress levels in children living } \\
\text { at home with their parents and } \\
\text { children living in institutional } \\
\text { protective care. }\end{array}$ \\
\hline
\end{tabular}




\section{Discussion}

There are many factors that affect temporomandibular joint dysfunction, including postural and structural disorders, occlusive abnormalities, bruxism, macrotrauma, or microtrauma $[15,16,17]$. According to Kindler et al., psychological factors may affect temporomandibular joint disorders through muscle hyperactivity, followed by biomechanical changes and related pain. They can lead to the formation of neurotransmitters disrupting the balance of catecholamines and serotonins. In addition, temporomandibular pain may be a physical manifestation of Common Mental Disorders [18]. In the research by Pereira et al. They emphasize the fact that the psychological aspect and female gender are important risk indicators associated with the occurrence of temporomandibular joint disorders [9]. Pizolato et al. Assessed that the level of anxiety and width of mouth opening are associated with temporomandibular joint disorders in children [10]. Al-Khotani et al. Proved that a group of patients with temporomandibular joint disorders accompanied by pain showed more frequent occurrence of anxiety problems and depression, as well as somatic complaints compared to the group without these disorders. It was also noted that aggressive behavior was more frequent in the pain group. Attention was drawn to the fact that in the pain group psychological problems were more frequent than in the group without pain and in the group where there were no problems with the temporomandibular joint [11]. Research by Kobayashi et al. Showed that there is no significant difference in levels of stress biomarkers, such as salivary amylase and cortisol, between children exhibiting temporomandibular joint disorders and children without this problem. It was noted, however, that children with TMD have a higher level of social anxiety [12]. A study by Sampaio et al. Showed that there are no significant associations between socio-demographic variables and bruxism occurring during sleep. A higher frequency of this disorder was also found in children whose mothers also suffered from this dysfunction. It was found that there is no significant relationship between the occurrence of bruxism during sleep and stress, both in children and their mothers [13]. The work of Sermet Elbay et al. Proved that the overall incidence of temporomandibular joint disorders and oral paraphunction was higher in children living in childcare centers than in children living with their parents. Children from childcare centers have proved more susceptible to this type of disorder. However, the relationship between the presentation of disorders in the oral cavity and the occurrence of stressful life situations was found in both examined groups [14].

\section{Summary}

The scientific literature used to create this review indicates that there is a relationship between mental and chronic stress disorders and the occurrence of temporomandibular joint disorders. All the analyzed works point to the fact that stress, anxiety or depression are often closely related to TMD. Bruxism also appears very often in research as a disorder related to psychological aspects. However, research in this area should continue to show more detailed information regarding both the general relationship between the abovementioned aspects and the relationship between individual temporomandibular joint disorders and psychological aspects.

\section{Literature}

1 F. Naikoo, A. Chalkoo, M. Ahmad, G. Yaqoob, S. Tariq; Prevalence and anxiety levels in patients with temporomandibular Disorder among Kashmiri population, 2017

2. M. Mielcarek, K. Złotnicka, K. Jaranowska, J. Borek, R. Malak, W. Samborski, Impact of temporomandibular joint disorders on body posture, Journal of Education, Health and Sport. 2019;9(10):160-165 
3. J.M. Borek, R.E. Malak, T. Matthews-Brzozowska, W. Samborski, Posturography examination as a diagnostic tool in children - a review of the literature, Journal of Medical Science, 2019, 88(1), 34-38

4. A. Stocka, J. Kuc, T. Sierpinska, M. Golebiewska, A. Wieczorek, The Influence of Emotional State on the masticatory muscles function in the group of young healthy adults. Bio Med Research International, 2015

5. H. Kanehira, A. Agariguchi, H. Kato, S. Yoshimine, and H. Inoue, "Association between stress and temporomandibular disorder," Nihon Hotetsu Shika Gakkai Zasshi, 2008, 52, (3): 375-380

6. S.E. Taylor, L.C.Klein, B.P.Lewis, T.L. Gruenewald, R.A. Gurung, J.A. Updegraff, Biobehavioral responses to stress in females: tend-and-befriend, not fight-or-flight, Psychol Rev, 2000, (107): 411-429

7. I.Y. Shin, R.S. Ahn, S.I. Chun, Y.J. Lee, M.S. Kim, C.K. Lee, S. Sung, Cortisol awakening response and nighttime salivary cortisol levels in healthy working Korean subjects. Yonsei Med J. 2011; 52:435- 444

8. A. Clow , L.Thorn, P. Evans, F. Hucklebridge, The awakening cortisol response: methodological issues and significance. Stress. 2004;7(1):29-37

9. L. Pereira, T. Pereira-Cenci, S. Pereira, A. Del Bel Cury, G. Ambrosano, A. Pereira, M. Gavião; Psychological factors and the incidence od temporomandibular disorders in early adolescence, 2009

10. R. Pizolato, F. de Freitas-Fernandes, M. Gavião; Anxiety/depression and orofacial myofacial disorders as factor associoated with TMD in children, 2013

11. A. Al-Khotani, A. Naimi-Akbar, M. Gjelset, E. Albadawi, L. Bello, B. HedenbergMagnusson, N. Christdis; The associations between psychological aspects and TMD-pain related aspects in children and adolescents, 2016

12. F.Y. Kobayashi, M.B.D Gaviao, M.C.S Marquezin, F.L.A. Fonseca, A.B.M. Montes, T.S. Barbosa, P.M. Castelo; Salivary stress biomarkers and anxiety symptoms in children with and without temporomandibular disorders, 2017

13. N.M. Sampaio, M.C. Oliveira, A.C. Andrade, L.B. Santos, M. Sampaio, A.Ortega; Relationship between stress and sleep bruxism in children and their mothers: A case control study, 2018

14. U. Sermet Elbay, H. Demirturk Kocasarac, M. Elbay, C. Kaya, C. Ugurluel, C. Baydemir; Temporomandibular disorders and oral parafunctions in children living with their parents and children living in institutional protective care: the comparisonal study, 2017

15. Y. Sakurai, A. Fujii, F. Kato; Persistent idiopathic facial pain associated with somatoform disorder in an 11-Year-Old Boy, 2019

16. V. Augusto, K. Perina, D. Penha, D.Santos, V. Oliveira; Temporomandibular dysfunction, stress and common mental disorder in University students, 2016

17. A. Mottaghi, S. Razavi, E. Pozveh, M. Jahangirmoghaddam; Assesment of the relationship between stress and temporomandibular disorder in female students before university entrance exam (Konkour exam), 2011

18. S. Kindler, S. Samietz, M. Houshmand, H. Jorgen Grabe, O. Bernhardt, R. Biffar, T. Kocher, G. Meyer, H. Volzke, H.r. Metelmann, Ch. Schwahn, Depressive and anxiety symptoms as risk factors for temporomandibular joint pain: a prospective cohort study in the general population, The Journal of Pain, 2012, 13 (12): 1188-1197 